\title{
POSITION
}

\section{BEHANDLING OG ANDRE POLITISKE HÅNDGRIBELIGHEDER}

STEFFEN JÖHNCKE

Er overdreven kærlighed et udtryk for en søgen efter mening - eller for en behandlingskrævende afhængighedslidelse? Psykologen Stanton Peele og psykiateren Archie Brodsky, begge amerikanere, udgav Love and Addiction første gang i 1975 (Peele \& Brodsky 1991). Deres væsentligste formål med bogen var at skabe kritisk opmærksomhed om, hvordan forståelsen af afhængighed som en biologisk sygdom var ved at blive dominerende i USA. Afhængighed er i denne forståelse udtryk for en individuel disposition, en overfølsomhed (i nogles version slet og ret en slags ,allergi“) over for bestemte ting, fx alkohol, som man kræver mere og mere af, hvis man først begynder, og til sidst helt mister kontrollen over. Peele og Brodsky mente, at denne sygdomstilgang afskærer en bredere opfattelse af, hvordan alle mennesker kan blive overdrevet og måske i problematisk grad opslugt af bestemte ting - ikke bare alkohol og stoffer: Kærlighed til et andet menneske kan også blive altfortærende og komme ud af kontrol, på godt og ondt. Når man i overdrevet grad søger tilfredsstillelse i én bestemt del af livet på bekostning af alt andet, er det ifølge Peele og Brodsky udtryk for eksistentielle problemer, eller at ens livsomstændigheder har været eller er for belastende, snarere end udtryk for en eller anden iboende biologisk brist. Hvis den bekræftelse og meningsfuldhed, man savner i livet, søges opfyldt ét sted fra, kan det blive „for meget“. Måske kan vi bruge denne almene erfaring og risiko for overdrivelse til at forstå og håndtere også afhængighed af alkohol og stoffer som udtryk for manglende mådehold og balance i tilværelsen? Måske ligger problemet med trangen til umådehold i den måde, vi lever vores liv på - eller i de sociale og familiemæssige vilkår, vi lever under - snarere end i en individuel, kropslig og specifik malfunktion over for eksempelvis alkohol?

Men ak, 16 år senere i forordet til andenudgaven af bogen (1991) må Peele og Brodsky give fortabt: Det var ikke den almenmenneskelige mulighed for overdrivelse, amerikanerne havde lagt sig på sinde, og de havde ikke brugt bogen 
til at gøre op med ideen om afhængighed som en særlig sygdom, nogle bliver ramt af. Det var faktisk slet ikke sådan, bogen fortrinsvis var blevet læst. Udviklingen havde tværtimod bevæget sig den anden vej, og også kærlighed var blevet opslugt af den omsiggribende sygeliggørelse af overdrivelse: Koerlighedsafhoengighed er blevet en etableret diagnose, i øvrigt sidenhen på linje med afhængighed af sex, mad, slankekure, spil, træning, TV, spænding, internet, arbejde, søvn, anerkendelse - af hvad som helst, der indgår i moderne menneskers liv. Afhængighedsbegrebet er blevet som en svamp, der suger alle former for manglende mådehold og balance til sig og tilbyder en forjættende forklaring: Du er syg - det er dit særlige (biologiske) vilkår.

Umiddelbart virker det befriende: Sygdom er hver mands herre, du er ikke selv skyld i den - det ligger i dine gener eller noget. Men ved nærmere eftersyn forskyder skylden og ansvaret sig imidlertid blot en anelse (Rose \& Novas 2005: 451): Du er måske ikke selv ansvarlig for årsagen, men du er personligt ansvarlig for at leve med sygdommen på den rette måde. Du skal i behandling for at lære at få din afhængighed under kontrol, og det er en livslang skæbne for dig.

Begreberne afhængighed og behandling kan i denne forbindelse kun forstås som et samlet hele - som et gensidigt forstærkende begrebspar, holdt sammen som minus og plus, som sygdom og truslen om undergang versus løftet om helbredelse og liv. Afhængighedsbegrebet næres af muligheden for behandling den individorienterede bearbejdning af de psykiske og kropslige tilstande, der holder afhængigheden ved lige. Behandling af afhængighed er i mange velfærdsstater (og i stigende grad også i fattigere lande) blevet en omfattende professionel aktivitet - eller som Stanton Peele i en anden bog (1995) betegner det: En behandlingsindustri, der har overbevist os om, at vi alle er kommet ud af kontrol i forhold til det ene eller andet - og har brug for behandling.

Behandling af afhængighed - af stoffer, alkohol, sex, internet osv. - er blevet en form for professionel ekspertise, der påberåber sig autoritativ viden om sit virkefelt, nemlig de afhængige. Behandling er en løsning, der definerer vores forståelse af problemet (Jöhncke 2009). Der findes andre behandlingsforståelser end de snævert sygdomsorienterede (Egelund \& Jakobsen 2006), men der lånes under alle omstændigheder autoritet til begrebet $\mathrm{i}$ den medicinske metaforik og forestillingen om helbredelse. I den almene, politiske debat fremstår behandling - om nødvendigt stadig mere og bedre behandling - som løsningen på afhængighedsproblemer. Forestillingen er så at sige, at vi kan behandle os til en afhængighedsfri befolkning. Behandling af afhængighed fremstår nu som en moralsk og politisk selvfølgelighed - vi kan da ikke ikke have behandling? især i en velfærdsstat som den danske. Derfor kan det også virke overraskende, at stadig mere forskning viser, at de fleste stof- og alkolholafhængige faktisk 
får styr på deres problemer med stoffer og alkohol uden brug af behandling (Granfield \& Cloud 1999; Klingemann \& Sobell 2007). Dette synes at være en af behandlingsindustriens velbevarede, markedstruende hemmeligheder, som ikke har politisk bevågenhed. Hvorfor ikke? kunne man spørge. Der plejer ellers nok at være vilje til at spare, hvor man kan.

Jeg skal være den første til at påpege, at alternativet til behandling ikke nødvendigvis er ingenting og gratis - tværtimod har mange med de største problemer med eksempelvis stoffer eller alkohol også nogle sociale vilkår eller andre livsomstændigheder, der nødvendiggør hjælp fra omgivelserne. Spørgsmålet er bare, om den individproblematiserende behandling vitterlig er den bedste hjælp? Eller om sagen er den, at behandling er tiltrækkende af andre årsager. Behandling virker - ganske vist ikke specielt godt på eksempelvis stofmisbrugere, hvis vi vurderer såkaldt stoffri behandling med fokus på afholdenhed: Effekten er stort set ringe, uanset hvad man gør (Pedersen et al. 2011). Stoffri behandling virker derimod på alle os andre ved at bidrage til at opretholde en bestemt form for politisk farmakologi (Asmussen \& Jöhncke 2004:15), dvs. bestemte forestillinger om stoffers iboende farlighed og nødvendigheden af kontrol. Myten om, at behandling er det eneste, der nytter (Jöhncke 2012), virker fremragende som et politisk budskab om, at problemet grundlæggende er individuelt, og at der ikke er noget galt med samfundets indretning og de vilkår for menneskelivet, det rummer.

Argumentet i denne Position er naturligvis ikke, at der intet godt og nyttigt arbejde gøres under overskriften „narkobehandling“ for at hjælpe mennesker i vanskelige eller endog livstruende omstændigheder. Det gør der bestemt. Argumentet er, at behandling - som aktivitet og begreb - gør en hel masse mere end det og former vores forståelse af menneskelige og samfundsmæssige problemer på bestemte måder og udelukker eller nedtoner andre.

Behandling er imidlertid ikke den eneste måde, hvorpå der sættes ind mod eksempelvis (overdrevet) alkoholforbrug og (ethvert) forbrug af illegale stoffer. Tværtimod har hele paletten af politiske og professionelle virkemidler historisk set været udfoldet $\mathrm{i}$ indsatsen. Brug af stoffer er som udgangspunkt en handling - eventuelt et handlemønster eller en „,adfærd“, om man vil. For så vidt som denne handling opfattes som afvigende og ønskes korrigeret, står der forskellige løsningsteknologier til rådighed. Omskiftelser og variationer i reaktioner på afvigende adfærd afspejler, hvordan politik, moral og viden forandrer sig over tid og sted. Til enhver problemforståelse knytter sig en bestemt løsningsforståelse - eller snarere, det ene kommer ikke før det andet, de to sider skabes i samme kulturelle begrebskompleks (Jöhncke et al. 2004) som i eksemplet med afhængighed og behandling. Lad mig komme pointen lidt nærmere med en oversigt, som 
hverken er udtømmende eller på anden måde ultimativ, men blot viser nogle ideelle (i betydningen: principielle og forestillede) sammenhænge mellem bestemte løsninger og problemer, som alle er eller har været taget $\mathrm{i}$ brug $\mathrm{i}$ indsatsen mod stofbrug som en form for afvigende adfærd.

\begin{tabular}{|l|l|}
\hline Løsning & Problem \\
\hline Forbud & Fare \\
\hline Straf & Forbrydelse \\
\hline Oplysning og uddannelse & Uvidenhed \\
\hline Vejledning, retledning & Forvildelse, vildspor \\
\hline Rådgivning & Uråd \\
\hline Trøst & Fortvivlelse \\
\hline Bekendelse og omvendelse & Synd og fortabelse \\
\hline Disciplin, selvdisciplin, selvudvikling & Uvaner, nykker, dovenskab, lyst \\
\hline Coaching, empowerment & Tvivl, selvæærdsproblemer, stress \\
\hline Bistand og omsorg & Nød og elendighed \\
\hline Forebyggelse & Risiko \\
\hline Behandling & Sygdom, afvigelse \\
\hline
\end{tabular}

Først og fremmest rummer lovgivningen, både den danske og den internationale, et meget omfattende og stadig voksende katalog over forbudte kemiske forbindelser, plantematerialer og andet, som erklæres ulovlige at fremstille og besidde (i forskellige mængder), fordi de skønnes at udgøre en fare for mennesker med hang til beruselse. At overtræde disse love er en forbrydelse, som forsøges modvirket ved at tildele straf. Unge og andre, der bruger stoffer alligevel, formodes i første omgang at være ramt af uvidenhed om stoffernes farlighed, hvorfor de må oplyses og uddannes om dette forhold. Det er altså at betragte som en forebyggelsesindsats mod en risiko. Hvis de stadig bruger stoffer, må man gå videre til andre virkemidler. Alle de nævnte begrebspar kan genfindes i talrige kombinationer i indsatsen mod stoffer hos forældre, skoler, sundhedsmyndigheder, kommunale instanser, politi, fængsler, behandlingsinstitutioner, gadeplansarbejdere, osv.

Det er klart, at der står Foucault $(1973,1979,1980)$ ud over det hele her: De i oversigten nævnte indsatser er ikke gensidigt udelukkende, men tværtimod dybt indvævede i hinanden i praksis. Selv om vi for eksempel vil mene, at synd i religiøs forstand ikke dominerer vores forståelse af misbrug i Danmark, er elementer af bekendelse og omvendelse dybt forankrede i tilgangen til rådgivning, vejledning og behandling. Moralen og virkemidlerne skifter udtryk, men mekanismerne til at ville skabe forandring kan genkendes. 
Pointen er imidlertid som nævnt også, at vægtningen vil skifte gennem tiden og variere mellem forskellige steder. Lad os tage andre eksempler på afvigende adfærd end stofbrug - seksualitet, for eksempel (for nu også at blive i den foucauldianske tradition). Hvis en fattig, ung kvinde i Danmark bliver gravid og får et barn uden at have en (mandlig) forsørger, kan man indledningsvist vælge slet ikke at betragte det som et problem, men som en glæde og som et bidrag til at bremse det faldende børnetal $i$ landet. Hvis man imidlertid betragter situationen som uønskelig, kan man vælge at opfatte det som udtryk for uvidenhed (ved hun ikke, hvordan man beskytter sig mod graviditet?), forvildelse (tror hun bare, at kommunen betaler/belønner?) eller lyst (uden øje for konsekvenserne!). Måske er det endog en slags forbrydelse mod almenvellet? Mens den velfærdspolitiske indsats i Danmark for kvinden vil være en kombination af rådgivning, bistand og disciplinering - fulgt af mere uformelle virkemidler i form af socialt stigma og mulig offentlig udhængning i medierne - vil man i andre lande måske snarere se, at kvinden har gjort sig skyldig i en forbrydelse (utugt eller tilsvarende), der skal straffes, eller en mental eller kropslig afvigelse, der skal behandles - i hvert fald, hvis det gentager sig. Danmark har historisk heller ikke holdt sig tilbage med at behandle kvinder, der var blevet kategoriseret som afvigere, og hvis afkom var uønsket, med tvungen sterilisation (Kragh et al. 2015). Tilsvarende var det muligt i Danmark frem til 1969 at behandle mænd med uønsket seksualitet, herunder homoseksuelle, ved hjælp af kastration.

Foranderligheden i problem-og-løsning-forholdet er netop pointen: Det er ikke givet, hvad der bliver rammesat hvordan - det er udtryk for skiftende historiske, politiske forhold. Det er heller ikke givet, at tingene kun går i én retning. Lad mig slutte med et eksempel, hvor behandling ikke er under afvikling, men udvikling: Indsatsen mod mænds køb af sex i Sverige. Prostitution forstået som de seksuelle handlinger, som prostituerede kvinder og mænd foretager med deres kunder mod betaling, har igennem historien vandret op og ned $\mathrm{i}$ hele det ovenstående skema og er i Danmark i dag endt som mere eller mindre tværsummen med elementer af det hele: Formel kriminalisering er afskaffet, men nogen anerkendelse af kvinders og mænds valg på dette felt er der heller ikke tale om. For en mand, derimod, har det at være kunde hos en prostitueret kvinde - men ikke hos en anden mand - gennem størstedelen af i hvert fald europæisk historie generelt været betragtet som maskulin normaladfærd. I det omfang, det har været problematiseret, har det været set som udtryk for nød, uråd, uvane eller andet i den lettere beklagelige afdeling. I Sverige fra 1980 'erne og frem skete der imidlertid en gradvis ændring (Östergren 2006), hvor der som led i ligestillingen af kønnene og bekæmpelsen af mænds vold mod kvinder blev politisk stemning for at gøre det ulovligt at betale for sex, hvilket blev iværksat med Sexköpslagen fra 1999, med en straframme 
på op til et halvt år, senere øget til ét år. Problematiseringen er imidlertid ikke stoppet dér, da det erfares, at straf alene ikke har den ønskede effekt på alle de pågældende mænd - der kræves behandling mod den politisk definerede lidelse „sexkøb“ for at få dem til at stoppe (Jansson 2010). I større byer som Stockholm og Göteborg findes således rådgivnings- og behandlingstilbuddet „KAST Köpare Av Sexuella Tjänster“, som tilbyder terapi til mænd, der ønsker at blive lovlydige borgere og afvikle deres tilbøjelighed til at have sex med kvinder mod betaling. Behandling for at være sexkøber er en logisk følge af udviklingen i den dominerende seksualpolitik og -moral i nutidens Sverige og er dermed et aktuelt eksempel på, at behandling, der retter sig mod adfærd, er politisk, før den er noget som helst andet.

\section{Litteratur}

Asmussen, Vibeke \& Steffen Jöhncke

2004 Indledning. Perspektiver på brugere. I: V. Asmussen \& S. Jöhncke (red.):

Brugerperspektiver - fra stofmisbrug til socialpolitik? Side 9-38.

Aarhus: Aarhus Universitetsforlag.

Egelund, Tine \& Turf Böcker Jakobsen (red.)

2006 Behandling i socialt arbejde. København: Hans Reitzels Forlag.

Foucault, Michel

1973 The Birth of the Clinic. An Archaeology of Medical Perception.

London: Tavistock.

1979 Discipline and Punish. The Birth of the Prison. New York: Vintage Books.

1980 The History of Sexuality, vol. 1. New York: Vintage Books.

Granfield, Robert \& William Cloud

1999 Coming Clean. Overcoming Addiction without Treatment. New York: New York University Press.

Jansson, Sanna

2010 „För att sluta köpa sex behövs behandling“. Göteborgs Fria, 21. januar. http://www.goteborgsfria.se/artikel/82207.

Jöhncke, Steffen

2009 Treatmentality and the Governing of Grug Use. Drugs and Alcohol Today 9(4): 14-17.

2012 Behandlingsmyten. Rus \& Samfunn 6(1):41-44.

Jöhncke, Steffen, Mette Nordahl Svendsen \& Susan Reynolds Whyte

2004 Løsningsmodeller. Sociale teknologier som antropologisk arbejdsfelt.

I: K. Hastrup (red.): Viden om verden. En grundbog i antropologisk analyse.

Side 385-407. København: Hans Reitzel.

Klingemann, Harald \& Linda C. Sobell (eds.)

2007 Promoting Self-change from Addictive Behaviors. Practical Implications for Policy, Prevention and Treatment. New York: Springer. 
Kragh, Jesper Vaczy, Stine Grønbæk Jensen, Jacob Knage Rasmussen \& Klaus Petersen

2015 Forskningsrapport. Anbragt i historien - et socialhistorisk projekt om anbragte og indlagte i perioden 1945-1980. www.anbragtihistorien.dk/.

Pedersen, Mads, Morten Hesse \& Kim Bloomfield

2011 Abstinence-oriented Residential Rehabilitation of Opioid Users in Denmark. Do Changes in National Treatment Policies Affect Treatment Outcome?

Scandinavian Journal of Public Health 39:582-89.

Peele, Stanton

1995 Diseasing of America. How We Allowed Recovery Zealots and the Treatment Industry to Convince Us We Are Out of Control. San Francisco: Jossey-Bass.

Peele, Stanton \& Archie Brodsky

$1991 \quad$ Love and Addiction. 2. Ed. New York: Taplinger.

Rose, Nikolas \& Carlos Novas

2005 Biological Citizenship. In: A. Ong \& S.J. Collier (red.): Global Assemblages. Technology, Politics, and Ethics as Anthropological Problems. Pp. 439-63.

Hoboken: Blackwell Publishing.

Östergren, Petra

2006 Porr, horor och feminister. Stockholm: Pocketförlaget. 
